\title{
Pathologies and mortality rates caused by organic carbon and nutrient stressors in three Caribbean coral species
}

\author{
Neilan M. Kuntz ${ }^{1,3}$, David I. Kline ${ }^{1,2,3}$, Stuart A. Sandin'², Forest Rohwer ${ }^{1,4, *}$ \\ ${ }^{1}$ Department of Biology, LS301, San Diego State University, 5500 Campanile Drive, San Diego, California 92182, USA \\ ${ }^{2}$ Center for Marine Biodiversity and Conservation, Scripps Institution of Oceanography, University of California, San Diego, \\ La Jolla, California 92093, USA \\ ${ }^{3}$ Smithsonian Tropical Research Institute, Apartado 2072, Balboa, Republic of Panama \\ ${ }^{4}$ Center for Microbial Sciences, San Diego State University, San Diego, California 92182, USA
}

\begin{abstract}
Anthropogenic inputs, including organic carbon and nutrient loading, are increasingly changing the water quality on coral reefs. Herein we show that treating Montastraea annularis, Agaricia tenuifolia and Porites furcata with various organic carbon sources (starch, lactose, arabinose and mannose) results in different species-specific and carbon-specific pathologies and rates of mortality. The variation in the pathological characteristics caused by stressors showed that visual cues for determining coral health and disease may be misleading. The probability of mortality increased significantly over time with continual exposure to several of the stressors, suggesting that chronic stressors may be more harmful than acute stressors. In contrast to the organic carbon sources, high concentrations of nutrients (phosphate, ammonium and nitrate) did not directly kill corals. The variation in coral responses to anthropogenic stressors means that changes on disturbed coral reefs will depend on the type of and duration of exposure to the stressor, as well as on the species of coral.
\end{abstract}

KEY WORDS: Coral $\cdot$ Disease $\cdot$ Symptoms $\cdot$ Chronic stress $\cdot$ Ecotoxicology

\section{INTRODUCTION}

Coral reefs are being severely changed by natural and anthropogenic stressors, resulting in a substantial decline of these ecosystems globally (Jackson et al. 2001, Gardner et al. 2003, Pandolfi et al. 2003). In the Caribbean, hard coral cover has been significantly degraded over the last 3 decades (Gardner et al. 2003). Growing human populations and projected climatic changes will result in more severe and variable stressors on coral reefs (Hughes et al. 2003). These changes will continue to test the survival of different coral species (Harvell et al. 1999, Green \& Bruckner 2000).

Diseases (Dustan \& Halas 1987, Aronson et al. 1998, Harvell et al. 1999) and bleaching events (Glynn 1993, Brown 1997, Hughes \& Connell 1999) have caused major phase shifts in coral reef communities (Knowlton et al. 1990, Hughes 1994, Harvell et al. 1999, Aronson et al. 2002). Determining species-specific differences in coral vulnerability to disease is critical for explaining and predicting changes on disturbed community structure. Previous studies have shown that closely related coral species demonstrate large differences in their response to disturbances (Marcus \& Thorhaug 1981, Fitt \& Warner 1995, Yap \& Molina 2003). Several coral species thrive in 'marginal' environments and proliferate on impacted reefs while others suffer high mortality. Porites furcata, for example, is abundant in disturbed environments, which experience extreme fluctuations in temperature, sedimentation and salinity that exclude most other coral species (e.g. Biscayne Bay, Florida; Lirman et al. 2003).

In this study, Montastraea annularis, Agaricia tenuifolia and Porites furcata were exposed to varying 
organic carbon sources (mono- and polysaccharides) and nutrients (combinations of phosphate, ammonium and nitrate). Our results show that the 3 coral species displayed different pathologies and mortality rates in response to these treatments.

\section{MATERIALS AND METHODS}

Coral collection and culturing system. Experiments were conducted at the Smithsonian Tropical Research Institute's Caribbean marine station in Bocas del Toro, Panama. The coral species were chosen because Montastraea annularis is the most common Caribbean reefbuilding species, while Agaricia tenuifolia and Porites furcata have become dominant shallow water corals since the decline of Acropora cervicornis due to white band disease (WBD; Aronson et al. 1998, 2002). Corals were collected from nearby waters using a hammer and chisel for $M$. annularis nubbins $(\sim 2$ to $3 \mathrm{~cm}$ diameter) and steel bone clippers for $A$. tenuifolia and $P$. furcata (both $\sim 4 \mathrm{~cm}$ length). In all cases, only the bare skeleton below the coral tissue was cut. Corals fragments were transported back to the field station in 191 buckets fitted with plastic separators to minimize damage. The fragments were allowed to recover for at least $1 \mathrm{wk}$ before beginning the experiments.

We conducted 2 experimental runs using a flowthrough treatment system called AADACS (Aquatic Automated Dosing and Culturing Systems; D. I. Kline \& F. Rohwer unpubl. data). Individual coral fragments were placed in separate $100 \mathrm{ml}$ polypropylene cups within 8 larger water baths to maintain ambient reef water temperature. The AADACS system was set up in a custom-made culturing room with a ceiling made of clear poly vinyl chloride (PVC) sheets and walls of window screening to increase the overall light levels in the room. Extra screening was used to equalize light levels among the baths. A light meter (Licor; Model LI-193SA) with a $4 \pi$ sensor was used to measure light levels just above each of the 8 water baths. Light levels at noon were $153.6 \pm 39.6 \mu \mathrm{E}$ on overcast days and $263.7 \pm 53.2 \mu \mathrm{E}$ on clear days.

The AADACS uses Venturi valves to automatically add treatments to incoming reef seawater just prior to entering the cup containing the coral. For these experiments, the AADACS was programmed to turn on for $6 \mathrm{~s}$ of each minute, completely replenishing each coral's water every $7.6 \pm 2.3 \mathrm{~min}$. Experimental runs were conducted during October and November 2003. Both runs lasted for $30 \mathrm{~d}$, with each coral nubbin's condition noted and photographed approximately every 3 d. For each experimental run, 10 nubbins of each coral species were exposed to the treatments and at least 10 nubbin controls were exposed to seawater only. Each of the 10 nubbins per treatment came from a separate coral colony.

Nutrient and organic carbon treatments. In the first 30 d experiment, Montrastraea annularis, Agaricia tenuifolia and Porites furcata fragments received 2 treatments: 5 and $25 \mathrm{mg} \mathrm{l}^{-1}$ of lactose. In separate treatments, all 3 corals species were exposed to combinations of nutrients. The 'high' nutrient doses were treatments of $2.5 \mu \mathrm{M}$ potassium phosphate, $25 \mu \mathrm{M}$ ammonium chloride and $7.5 \mu \mathrm{M}$ calcium nitrate; the 'low' nutrient doses were treatments of $0.5 \mu \mathrm{M}$ potassium phosphate, $5 \mu \mathrm{M}$ ammonium chloride and $2.5 \mu \mathrm{M}$ calcium nitrate. In the second $30 \mathrm{~d}$ experiment, $M$. annularis and $P$. furcata were separately exposed to $25 \mathrm{mg} \mathrm{l}^{-1}$ of starch, lactose, arabinose and mannose. All treatment concentrations reflect levels previously reported for impacted reefs (March 1977, Webber \& Roff 1995, Costa et al. 2000, Van Duyl \& Gast 2001).

Statistical analyses. The cumulative effects of the treatments on coral survivorship throughout the $30 \mathrm{~d}$ of each experiment were compared for each coral species. Coral mortality of each colony was recorded as a continuous variable representing the fraction of the colony with dead polyps. A polyp was considered dead when all tissue was lost from the skeleton. Each Montastraea annularis nubbin had approximately 30 to 70 polyps. Mortality was more frequently complete (i.e. 1 whole nubbin) than partial (i.e. a fraction of the nubbin), resulting in a severely non-normal distribution of mortality within each treatment. Therefore, a non-parametric rank test (Kruskal-Wallis test with corrections for ties and unequal sample sizes; Zar 1984) was used to compare differences in relative mortality across treatments. Post-hoc multiple comparisons using rank sums (again with corrections for ties and unequal sample sizes; Dunn 1964) were computed for species in experiments with significant differences among treatments to determine the outlying groups. Because the differences of coral mortality with and without altered seawater were being tested, post-hoc tests on the comparisons of treatment against control were used. To be conservative, results were tested against 2-tailed probability distributions, although using a 1-tailed test (assuming that treatments will only have increased mortality relative to controls) would not have changed the results.

To test for qualitative differences in the pathology of each treatment, the patterns of mortality were explored throughout the experiment. Given counts of coral survivorship over time, the per capita daily rate of mortality for each treatment, $m_{s}$, for the days preceding Sample $s$ were computed as $m_{s}=1-\left(n_{s} / n_{s-1}\right)^{1 / t_{s}-t_{s-1}}$, where $n_{s}$ is the number of corals alive and $t_{s}$ is the time (d) at Sample $s$. Note that for these analyses partial morality was ignored and only the entire colony lost was considered, thus constraining all $n_{S}$ to integers. 
The data were fit to 2 models of mortality rate over time: (1) constant mortality over time, or $m_{t}=m$ for all Time $t$, and (2) mortality as a function of time. To allow maximum flexibility of this second mortality rate function while constraining the value between 0 and 1 , the logistic equation $\mu_{t}=\left[1+\left(\beta^{-1}+1\right) \exp (-\alpha t)\right]^{-1}$ was used, where $\alpha$ and $\beta$ were estimated parameters. Maximum likelihood techniques were used to identify the best-fit parameters for each model for each treatment. Given estimated parameters ( $m$ for Model 1 and both $\alpha$ and $\beta$ for Model 2), a per capita probability of mortality, $m_{t}$, for each of the $30 \mathrm{~d}$ of the experiment was calculated. The probability of there being $n_{\mathrm{s}}$ corals alive in Sample $s$ was a function of the number of corals alive in the previous sample, $n_{s-1}$, and of the daily per capita mortality probabilities, $m_{t}$, for days $\left[t_{s-1},\left(t_{s}-1\right)\right]$. The probability of the number of surviving corals changing from $n_{s-1}$ to $n_{s}$ was computed as

$\operatorname{Pr}\left(n_{S} \mid n_{s-1}\right)=$

$\sum_{i=n_{s}}^{n_{s-1}} \sum_{j=n_{s}}^{i} \ldots \sum_{y=n_{s}}^{x} \operatorname{bin}\left(i, n_{s-1}, 1-\mu_{s-1}\right) \operatorname{bin}\left(j, i, 1-\mu_{t_{s-1}+1}\right) \ldots \operatorname{bin}\left(n_{s-1}, y, 1-\mu_{t_{s-1}}\right)$

where bin $(a, b, 1-m)$ was the binomial probability of having $a$ individuals alive in the next time step after starting with $b$ individuals with a per capita probability of survivorship, $1-m$. The number of summations in Eq. (1) was the number of days separating Samples $s-1$ and $s$. Summing the probability from Eq. (1) across all samples of coral survivorship samples during the $30 \mathrm{~d}$ run produced the total probability of the data given mortality function $m_{t}$. The log-likelihood value is the logarithm of this total probability. For each of the 2 models, parameter space was explored to identify the best-fitting parameter (or the combination of parameters, for the logistic model) that resulted in the maximum log-likelihood value.

To test whether the mortality probability changed with time, the 2 best-fit models for each treatment were compared to determine relative fit of each model. Because the time-independent mortality model was nested within the logistic model (as by setting $\alpha$ to zero in the logistic model), a simple statistical test for the presence of time-dependent mortality could be used (i.e. the likelihood ratio test; Hilborn \& Mangel 1997). Specifically, the estimate of $\alpha$ was significantly different from zero at the $\mathrm{p}<0.05$ level if the log-likelihood of the best-fit logistic mortality model was larger by $>1.92$ than the log-likelihood of the best-fit nested time-independent mortality model $\left(1.92=0.5 \cdot X^{2}{ }_{0.05(1)}\right.$, because the time-dependent model had 1 more parameter than the nested time-independent model). Thus, a significant value of $\alpha$ means that the rate of mortality for that treatment changes significantly over time.

\section{RESULTS}

\section{Mortality and pathology caused by different levels of lactose}

Lactose treatments caused significant mortality of Montastraea annularis and Agaricia tenuifolia (KruskalWallis $H_{\mathrm{c}}=27.3$ and 13.7, respectively; $\mathrm{df}=2, \mathrm{p}<0.05$ for both), but not of Porites furcata (Kruskal-Wallis $H_{\mathrm{C}}=$ $2.42, \mathrm{df}=2, \mathrm{p}>0.25$ ). The high lactose treatment (25 $\mathrm{mg} \mathrm{l}^{-1}$ ) caused significant mortality of $M$. annularis relative to the control (90 vs. $10 \%$; p < 0.001). Both the 5 and $25 \mathrm{mg} \mathrm{l}^{-1}$ treatments of lactose caused significant mortality of $A$. tenuifolia relative to control (77 vs. $73 \%$, respectively, vs. $10 \%$ for control; $p<0.02$ for both). In contrast, the 5 and $25 \mathrm{mg} \mathrm{l}^{-1}$ lactose treatments caused no significant mortality of $P$. furcata at either concentration after $30 \mathrm{~d}(27$ and $23 \%$, respectively, vs. $10 \%$ for control; p >0.1, Fig. 1). With the high

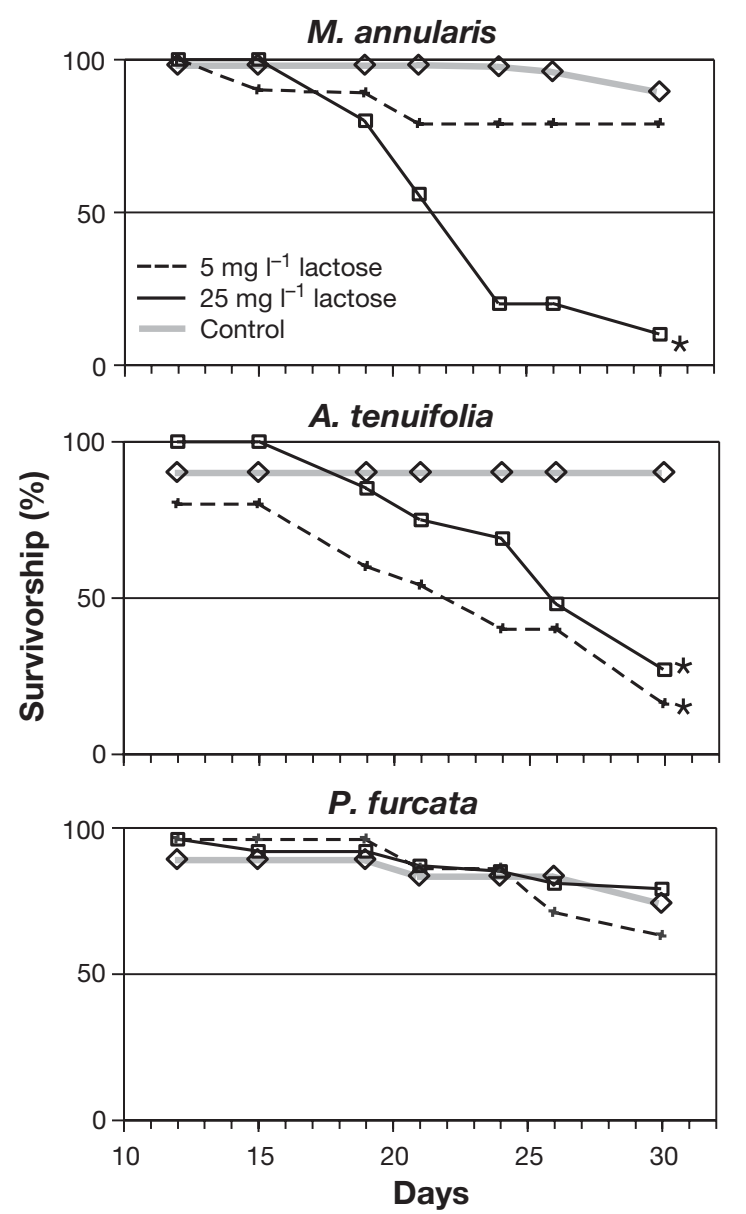

Fig. 1. Montastraea annularis, Agaricia tenuifolia and Porites furcata. Variation in coral survivorship during exposure to 5 and $25 \mathrm{mg} \mathrm{l}^{-1}$ lactose over a $30 \mathrm{~d}$ period. *: Significant mortality of $M$. annularis and $A$. tenuifolia; control sample size $=49$ nubbins for M. annularis and 10 each for A. tenuifolia and P. furcata; 10 nubbins were used in all treatments 
Table 1. Montastraea annularis, Agaricia tenuifolia and Porites furcata. Pathologies observed during treatment with different nutrient and lactose concentrations. 'Low' nutrients: $0.5 \mu \mathrm{M}$ potassium phosphate, $5 \mu \mathrm{M}$ ammonium chloride, $2.5 \mu \mathrm{M}$ calcium nitrate; high nutrients: $2.5 \mu \mathrm{M}$ potassium phosphate, $25 \mu \mathrm{M}$ ammonium chloride, $7.5 \mu \mathrm{M}$ calcium nitrate.

\begin{tabular}{|c|c|c|c|c|}
\hline \multirow{2}{*}{ Species } & \multicolumn{2}{|c|}{ - Lactose concentration } & \multicolumn{2}{|c|}{ Nutrient concentration } \\
\hline & $5 \mathrm{mg} \mathrm{l}^{-1}$ & $25 \mathrm{mg} \mathrm{l}^{-1}$ & Low & High \\
\hline M. annularis & $\begin{array}{l}\text { Progressive mortality } \\
\text { beginning along coral edge }\end{array}$ & Sloughing of tissue in 1 event & Bleaching & $\begin{array}{l}\text { Bleaching; } \\
\text { partial mortality along edges }\end{array}$ \\
\hline A. tenuifolia & $\begin{array}{l}\text { Progressive mortality } \\
\text { beginning along coral edge }\end{array}$ & $\begin{array}{l}\text { Bleaching of conosteum or } \\
\text { entire coral bleaching; } \\
\text { progressive mortality beginning } \\
\text { along coral edge }\end{array}$ & $\begin{array}{l}\text { Bleaching; } \\
\text { partial mortality, } \\
\text { beginning along } \\
\text { edges }\end{array}$ & $\begin{array}{l}\text { Bleaching; } \\
\text { partial mortality along edges }\end{array}$ \\
\hline P. furcata & $\begin{array}{l}\text { Retraction of polyps; } \\
\text { progressive mortality } \\
\text { beginning at coral edge }\end{array}$ & $\begin{array}{l}\text { Retraction of polyps; } \\
\text { increased mucus secretion; } \\
\text { progressive mortality beginning } \\
\text { at coral edge }\end{array}$ & $\begin{array}{l}\text { Nothing } \\
\text { observed }\end{array}$ & Retraction of polyps \\
\hline
\end{tabular}

lactose treatment, the rate of mortality (lethal time until $50 \%$ mortality, $\mathrm{LT}_{50}$ ) was 21 and 26 d for $M$. annularis and A. tenuifolia, respectively. At the lower lactose dosage, A. tenuifolia had an $\mathrm{LT}_{50}$ of $24 \mathrm{~d}$.

Sublethal effects of the lower lactose treatment $\left(5 \mathrm{mg} \mathrm{l}^{-1}\right)$ were similar in all 3 coral species, including partial tissue loss at the edges (Table 1). Pathologies associated with the higher lactose treatment $\left(25 \mathrm{mg} \mathrm{l}^{-1}\right)$ varied among the 3 coral species. Agaricia tenuifolia displayed bleaching of the coenosteum of the entire coral followed by progressive mortality, which began along the coral's edge until it destroyed the fragment. In contrast, Montastraea annularis usually appeared healthy until all the tissue sloughed off the coral.

\section{Species-specific mortality caused by different carbon sources}

Montastraea annularis and Porites furcata demonstrated distinct trends in response to different carbon sources (Fig. 2). For example, mannose caused significant mortality of $P$. furcata relative to the con-

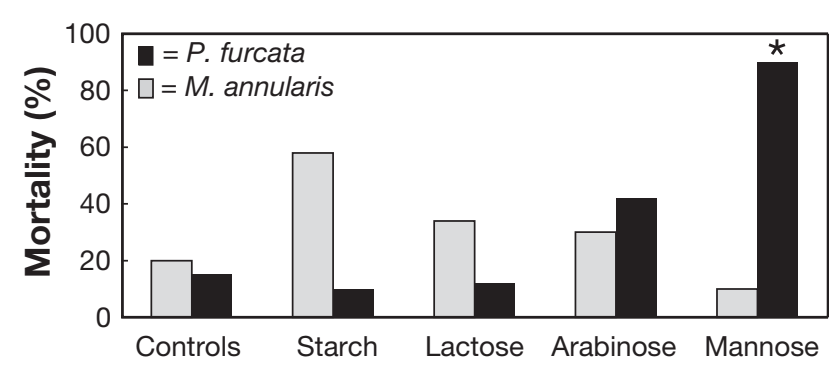

Fig. 2. Montastraea annularis and Porites furcata. Percent mortality after exposure to various mono- and polysaccharides $\left(25 \mathrm{mg} \mathrm{l}^{-1}\right.$ ) for $30 \mathrm{~d}$. *: Significant mortality; sample size $=10$ for both treatments and controls trol (90 vs. $15 \%, \mathrm{p}<0.001)$, but did not affect $M$. annularis.

Some of the Porites furcata corals were bleached from the arabinose exposure, while the mannose treatment produced progressive mortality that began at the coral tip. Pathologies associated with Montastraea annularis exposed to the different sugars were similar to those for lactose. The progressive mortality due to increased carbon levels resulted in a clear demarcation, in the form of a banding pattern between the degrading tissue and dead coral in $23 \%$ of the lethal cases (Fig. 3). The progression of mortality was symptomatically reminiscent of several coral diseases (review by Richardson 1998).

\section{Mortality and pathologies caused by elevated nutrients}

Combinations of potassium phosphate $(2.5 \mu \mathrm{M})$, ammonium chloride $(25 \mu \mathrm{M})$ and calcium nitrate $(7.5 \mu \mathrm{M})$ had caused no significant coral mortality after 30 d (Fig. 4): Agaricia tenuifolia $\left(H_{\mathrm{c}}=4.2, \mathrm{df}=2, \mathrm{p}>\right.$ $0.1)$, Montastraea annularis $\left(H_{\mathrm{c}}=2.4\right.$, $\left.\mathrm{df}=2, \mathrm{p}>0.25\right)$, and Porites furcata $\left(H_{\mathrm{c}}=0.6, \mathrm{df}=2, \mathrm{p}>0.75\right)$. Some of the $M$. annularis nubbins bleached at both nutrient levels, as did some of the A. tenuifolia fragments at the 'high' nutrient concentrations (Table 1).

\section{Time-dependent mortality}

Exposure to chronic stress caused a significant increase in the likelihood of coral mortality in some treatments (Fig. 5). In the first $30 \mathrm{~d}$ experiment, mortality increased significantly for the high lactose treatments with Montastraea annularis and both lactose level treatments with Agaricia tenuifolia (Fig. 5A). The timedependent mortality in the second experiment was 

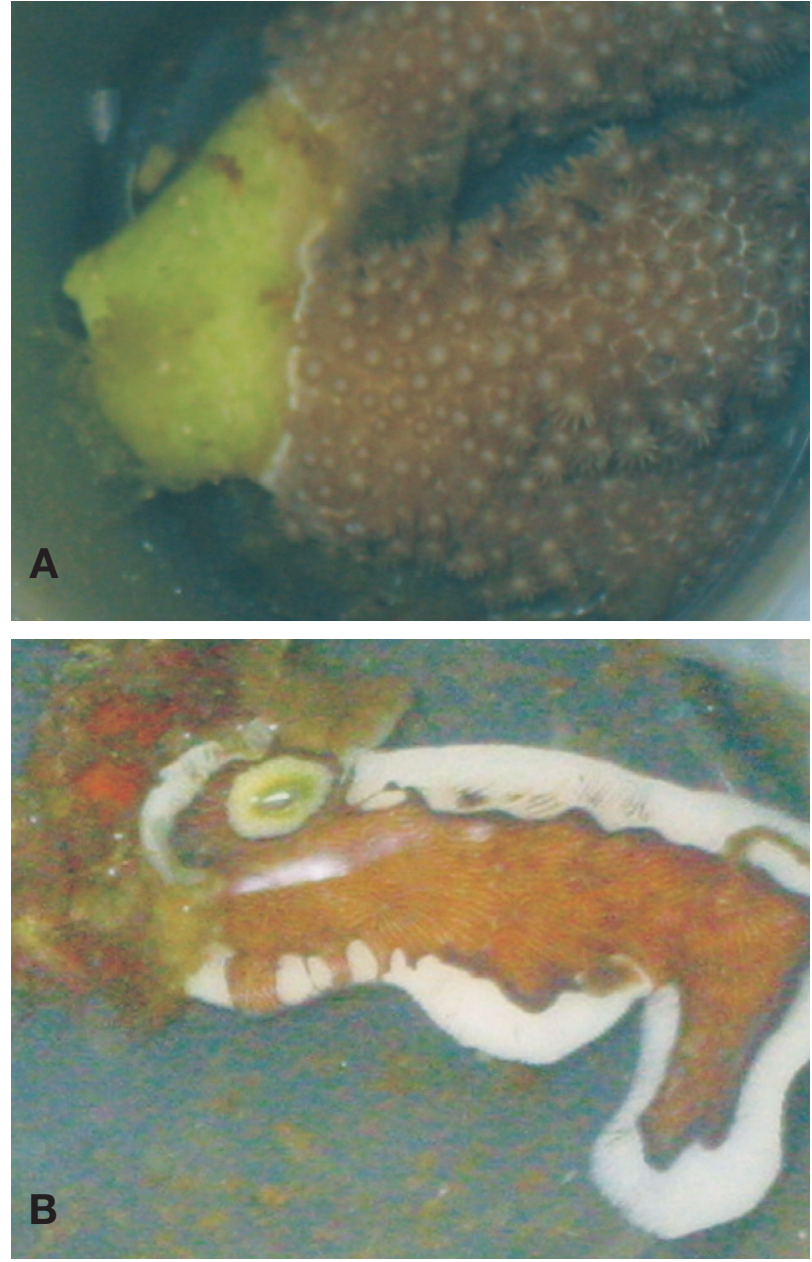

Fig. 3. Agaricia tenuifolia and Porites furcata. Examples of progressive mortality arising from increased lactose levels in (A) A. tenuifolia (25 mg $\mathrm{l}^{-1}$ lactose at $30 \mathrm{~d}$ ) and (B) P. furcata (25 $\mathrm{mg} \mathrm{l}^{-1}$ lactose at $21 \mathrm{~d}$ )

significant with starch and cellulose treatments of $M$. annularis and mannose exposure for Porites furcata (Fig. 5B).

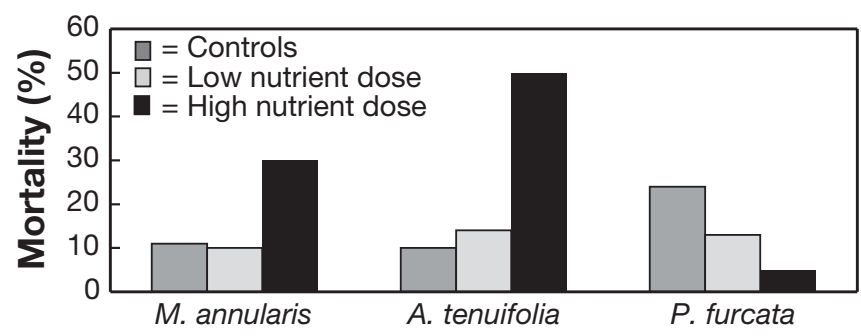

Fig. 4. Montastraea annularis, Agaricia tenuifolia and Porites furcata. Mortality after exposure to different levels of nutrients containing mixtures of ammonium, phosphate and nitrate (see 'Nutrient and organic treatments' for details of low and high nutrient doses). Control sample size $=49$ for $M$. annularis and 10 each for $A$. tenuifolia and $P$. furcata

\section{DISCUSSION}

\section{Variation in coral pathologies}

Coral diseases have, by necessity, been described based on pathology (review by Richardson 1998). No ubiquitous pathological characteristics, however, were associated with increased nutrients or organic carbon levels. This means that a specific stressor can elicit multiple pathologies that vary between coral species (Table 1). The discrepancy in visual pathologies illustrates the limitation of traditional methods for assessing coral health. Similarly, the sudden 'sloughing' of tissue in what had previously appeared to be a healthy Montastraea annularis highlights the need for better markers for the assessment of coral health. Fitt \& Warner (1995) also noted a rapid tissue sloughing from 'healthy' colonies when $M$. annularis was subjected to increased seawater temperature up to $34^{\circ} \mathrm{C}$. Microscopic analyses have shown that there is a subdermal layer of microbes in stressed corals just prior to such rapid mortality events (O. Pantos pers. comm.).

Pantos et al. (2003) showed that the bacterial community on apparent 'healthy tissue' of white plaguediseased Montastraea annularis differed significantly from that on healthy tissue of an uninfected and unstressed colony. Together these observations suggest that a coral's response to stress frequently involves changes in the microbial community, and the response of the holobiont may be an effective tool in identifying stress in coral colonies before visible symptoms appear (Pantos et al. 2003). Molecular measurements have also been proposed as bioassays for coral health (Burns 1993, Harriot 1993, Downs et al. 2000). Logistical limitations, however, may make molecular techniques too difficult for rapid coral health assessments. A tool that is deployable and responsive in situ and combines data from several of a coral's symbionts is greatly needed. Potential targets could be in situ ATP measurements to determine microbial activity or fluorometry with DNA stains to monitor microbial numbers.

\section{Increased probability of mortality with chronic stressor}

In these experiments, the probability of mortality increased significantly with continual exposure to several of the stressors. This effect was noted for all of the stressors found to cause significant mortality after a $30 \mathrm{~d}$ period (Fig. 5). These results show that the impact of a chronic stress on susceptible species is not constant, but instead has an increasingly potent effect over time. Chronic stress has been shown to have a devas- 

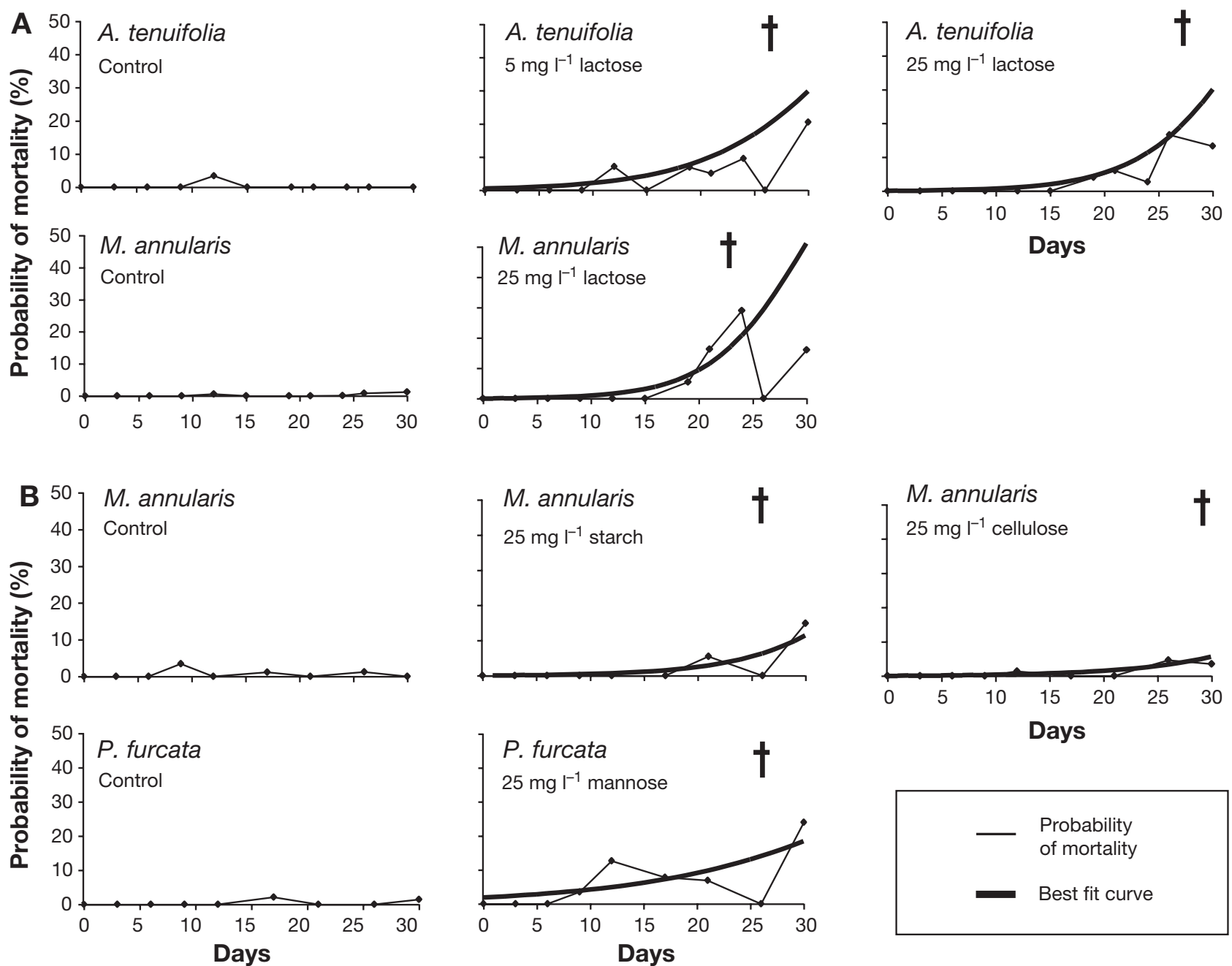

Fig. 5. Montastraea annularis, Agaricia tenuifolia and Porites furcata. Time-dependent mortality during exposure to chronic stressor over a $30 \mathrm{~d}$ period. Exposure was to (A) lactose and (B) various mono- and polysaccharides. Probability of mortality was computed as per capita daily rate of mortality for each treatment. ( ) Actual daily probability of mortality; $†$ : significant rate of mortality changes over time as indicated by time-dependent model

tating effect on coral reef systems (Walker \& Ormond 1982, Scott 1990). Sewage runoff into tropical marine systems is considered one of the principal causes of coral reef degradation (Risk \& Erdmann 2000). Continual sewage input (a major source of organic carbon) has been shown to severely depress and eliminate the coral coverage in an immediate discharge area of Honolulu, Hawaii (Mamala Bay; Grigg 1995). This is especially worrisome because most coral reefs are in less economically developed regions of the world, where wastewater treatment is limited or non-existent. Distinguishing the effects of chronic and acute stress remains an outstanding problem in ecotoxicological studies on coral reefs. Responses of corals and their symbionts to anthropogenic stressors will depend on the period of exposure to those stressors. These results highlight the fact that coral mortality patterns may depend on each type of stressor, the species of coral, and the duration of exposure time.

\section{Differential effects of stressors on corals and coral holobiont}

Corals naturally harbor Bacteria and Archaea (DiSalvo 1971, DiSalvo \& Gundersen 1971, Ducklow \& Mitchell 1979, Ritchie \& Smith 1995, 1997, Rohwer et al. 2001, 2002, Kellogg 2004, Wegley et al. 2004), as well as zooxanthellae, endolithic algae (Bentis et al. 2000) and endolithic fungi (Odum \& Odum 1955, Shashar et al. 1997). Disrupting the coral-microbe relationship by organic carbon loading (e.g. glucose) can directly cause 
coral mortality by over-stimulating growth of coral mucus-associated microbes (Mitchell \& Chet 1975, D. I. Kline \& F. Rohwer unpubl. data). We propose that variation in coral responses to stressors may be mediated by species-specific dynamics of the symbiont community (Rohwer \& Kelley 2004), similar to the variation observed in bleaching based on zooxanthellae type (Rowan et al. 1997, Toller et al. 2001). Additional experiments are needed to determine how nutrient and organic carbon loading changes the composition and/or dynamics of the coral-associated microbial communities. Resolving this distinction will advance greatly our understanding of the complex and dynamic changes occurring in coral communities today.

Acknowledgements. This research was supported by a grant from the National Science Foundation Biological Oceanography (OCEO1-37748) to F.R. The authors thank the Smithsonian Tropical Research Institute field station in Panama for the use of their facilities and the Republic of Panama (Autoridad Nacional del Ambiente, Departamento de Cuarentena Agropecuaria del Ministerio de Desarollo Agropecuaria) for permission to collect corals.

\section{LITERATURE CITED}

Aronson RB, Precht WF, Macintyre IG (1998) Extrinsic control of species replacement on a Holocene reef in Belize: the role of coral disease. Coral Reefs 17:223-230

Aronson RB, MacIntyre IG, Precht WF, Murdoch TJT, Wapnick CM (2002) The expanding scale of species turnover events on coral reefs in Belize. Ecol Monogr 72:233-249

Bentis CJ, Kaufman L, Golubic S (2000) Endolithic fungi in reef-building corals (order: Scleractinia) are common, cosmopolitan, and potentially pathogenic. Biol Bull (Woods Hole) 198:254-260

Brown B (1997) Coral bleaching: causes and consequences. Proc 8th Int Coral Reef Symp 1:65-74

Burns KA (1993) Evidence for the importance of including hydrocarbon oxidation products in environmental assessment studies. Mar Pollut Bull 27:199-205

Costa OS, Leao ZMAN, Nimmo M, Attrill MJ (2000) Nutrification impacts on coral reefs from northern Bahía, Brazil. Hydrobiologia 440:307-315

DiSalvo LH (1971) Regenerative functions and microbial ecology of coral reefs: labelled bacteria in a coral reef microcosm. J Exp Mar Biol Ecol 7:123-136

DiSalvo LH, Gundersen K (1971) Regenerative functions and microbial ecology of coral reefs. I. Assays for microbial population. Can J Microbiol 17:1081-1089

Downs CA, Mueller E, Phillips S, Fauth JE, Woodley CM (2000) A molecular biomarker system for assessing the health of coral (Montastraea faveolata) during heat stress. Mar Biotechnol 2:533-544

Ducklow HW, Mitchell R (1979) Bacterial populations and adaptations in the mucus layers on living corals. Limnol Oceanogr 24:715-725

Dunn OJ (1964) Multiple contrasts using rank sums. Technometrics 6:241-252

Dustan P, Halas JC (1987) Changes in the reef-coral community of Carysfort Reef, Key-Largo, Florida - 1974 to 1982. Coral Reefs 6:91-106
Fitt WK, Warner ME (1995) Bleaching patterns of 4 species of Caribbean reef corals. Biol Bull (Woods Hole) 189:298-307

Gardner TA, Cote IM, Gill JA, Grant A, Watkinson AR (2003) Long-term region-wide declines in Caribbean corals. Science 301:958-960

Glynn PW (1993) Coral reef bleaching ecological perspectives. Coral Reefs 12:1-17

Green EP, Bruckner AW (2000) The significance of coral disease epizootiology for coral reef conservation. Biol Conserv 96:347-361

Grigg RW (1995) Coral reefs in an urban embayment in Hawaii. A complex case history controlled by natural and anthropogenic stress. Coral Reefs 14:253-266

Harriott VJ (1993) Coral lipids and environmental stress. Environ Monit Assess 25:131-139

Harvell CD, Kim K, Burkholder JM, Colwell RR and 9 others (1999) Emerging marine diseases-climate links and anthropogenic factors. Science 285:1505-1510

Hilborn R, Mangel M (1997) The ecological detective. Princeton University Press, Princeton, NJ (315)

Hughes TP (1994) Catastrophes, phase-shifts, and largescale degradation of a Caribbean coral-reef. Science 265: $1547-1551$

Hughes TP, Connell JH (1999) Multiple stressors on coral reefs: a long-term perspective. Limnol Oceanogr 44:932-940

Hughes TP, Baird AH, Bellwood DR, Card M and 13 others (2003) Climate change, human impacts, and the resilience of coral reefs. Science 301:929-933

Jackson JBC, Kirby MX, Berger WH, Bjorndal KA and 15 others (2001) Historical overfishing and the recent collapse of coastal ecosystems. Science 293:629-638

Kellogg C (2004) Tropical Archaea: Diversity associated with the surface microlayer of corals. Mar Ecol Prog Ser 272: 81-88

Knowlton N, Lang JC, Keller BD (1990) Case study of natural population collapse: post-hurricane predation on Jamaican staghorn corals. Smithson Contrib Mar Sci 31:1-25

Lirman D, Orlando B, Macia S, Manzello D, Kaufman L, Biber P, Jones T (2003) Coral communities of Biscayne Bay, Florida and adjacent offshore areas: diversity abundance, distribution, and environmental correlates. Aquat Conserv-Mar Fresh Ecosys 13:121-135

Marcus J, Thorhaug A (1981) Pacific versus Atlantic responses to the subtropical hermatypic coral Porites spp. to temperature and salinity effects. Proc 4 th Int Coral Reef Symp 2:15-20

Marsh JA (1977) Terrestrial inputs of nitrogen and phosphorus on fringing reefs on Guam. Proc 3rd Int Coral Reef Symp 1:331-336

Mitchell R, Chet I (1975) Bacterial attack of corals in polluted seawater. Microb Ecol 2:227-233

Odum HT, Odum EP (1955) Trophic structure and productivity of a windward coral reef community on Eniwetok Atoll. Ecol Monogr 25:291-320

Pandolfi JM, Bradbury RH, Sala E, Hughes TP and 8 others (2003) Global trajectories of the long-term decline of coral reef ecosystems. Science 301:955-958

Pantos O, Cooney R, Le Tissier M, Barer M, O'Donnell A, Bythell J (2003) The bacterial ecology of a plague-like disease affecting the Caribbean coral Montastraea annularis. Environ Microbiol 5:370-382

Richardson LL (1998) Coral disease: What is really known? Trends Ecol Evol 13:438-443

Risk MJ, Erdmann MV (2000) Isotopic composition of nitrogen in stomatopod (Crustacea) tissues as an indicator of human sewage impacts on Indonesian coral reefs. Mar Pollut Bull 40:50-58 
Ritchie KB, Smith GW (1995) Preferential carbon utilization by surface bacterial communities from water mass, normal, and white-band diseased Acropora cervicornis. Mol Mar Biol Biotech 4:345-354

Ritchie KB, Smith GW (1997) Physiological comparison of bacterial communities from various species of scleractinian corals. Proc 8th Int Coral Reef Symp 1:521-526

Rohwer F, Kelley S (2004) Corals as microbial landscapes. In: Rosenberg E, Loya Y (eds) Coral health and disease. Springer-Verlag, New York, p 265-275

Rohwer F, Breitbart M, Jara J, Azam F, Knowlton N (2001) Diversity of bacteria associated with the Caribbean coral Montastraea franksi. Coral Reefs 20:85-95

Rohwer F, Seguritan V, Azam F, Knowlton N (2002) Diversity and distribution of coral-associated bacteria. Mar Ecol Prog Ser 243:1-10

Rowan R, Knowlton N, Baker A, Jara J (1997) Landscape ecology of algal symbionts creates variation in episodes of coral bleaching. Nature 388:265-269

Scott PJB (1990) Chronic pollution recorded in coral skeletons in Hong Kong. J Exp Mar Biol Ecol 139:51-64

Shashar N, Banaszak AT, Lesser MP, Amrami D (1997) Coral endolithic algae: life in a protected environment. Pac Sci

Editorial responsibility: Otto Kinne (Editor-in-Chief), Oldendorf/Luhe, Germany
51:167-173

Toller WW, Rowan R, Knowlton N (2001) Repopulation of zooxanthellae in the Caribbean corals Montastraea annularis and Montastraea faveolata following experimental and disease-associated bleaching. Biol Bull (Woods Hole) 201:360-373

Van Duyl FC, Gast GJ (2001) Linkage of small-scale spatial variations in DOC, inorganic nutrients and bacterioplankton growth with different coral reef water types. Aquat Microb Ecol 24:17-26

Walker DI, Ormond RFG (1982) Coral death from sewage and phosphate pollution at Aqaba, Red Sea. Mar Pollut Bull 13:21-25

Webber MK, Roff JC (1995) Annual structure of the copepod community and its associated pelagic environment off Discovery Bay, Jamaica. Mar Biol 123:467-479

Wegley L, Casas V, Yu Y, Breitbart M, Rohwer F (2004) Coralassociated Archaea. Mar Ecol Prog Ser 273:89-96

Yap HT, Molina RA (2003) Comparison of coral growth and survival under enclosed, semi-natural conditions and in the field. Mar Pollut Bull 46:858-864

Zar JH (1984) Biostatistical analysis, 2nd edn. Prentice-Hall, Englewood Cliffs, NJ

Submitted: August 9, 2004; Accepted: February 10, 2005

Proofs received from author(s): May 27, 2005 